\title{
PENGARUH COGNITIVE BEHAVIOUR THERAPY (CBT) TERHADAP ANSIETAS REMAJA DI WILAYAH RAWAN BANJIR
}

\author{
Fajriyah Nur Afriyanti ${ }^{2}$, Mustikasari $^{2}$, Herni Susanti ${ }^{2}$ \\ ${ }^{1}$ Universitas Islam Negeri Syarif Hidayatullah Jakarta, Jakarta \\ (Email: fajriyah.na@gmail.com) \\ ${ }^{2}$ Fakultas Ilmu Keperawatan, Universitas Indonesia, Depok
}

\begin{abstract}
ABSTRAK
Objektif : Remaja cenderung beresiko mengalami ansietas yang disebabkan oleh kejadian bencana alam. Penelitian ini bertujuan untuk mengidentifikasi pengaruh cognitive behaviour therapy (CBT) terhadap tingkat ansietas remaja di wilayah banjir.

Metode: Desain peneliatian Quasi experimental with control group pretest-posttest dengan tekhik purposive sampling dan dilanjutkan cluster random sampling. Terdapat 73 sampel yaitu 37 intervensi dan 36 kontrol, dan tindakan keperawatan ners dan CBT sebanyak 4 kali pertemuan.

Hasil: hasil menujukkan bahwa ada penurunan yang signifikan dari tingkat ansietas (p-value <0,05) pada kelompok yang dirawat dengan menggunakan intervensi keperawatan ners dan CBT, serta penurunan signifikan lebih besar daripada kelompok yang hanya diintervensi dengan keperawatan ners.

Kesimpulan: CBT dapat menurunkan tingkat ansietas pada remaja di wilayah bencana banjir, sehingga dapat direkomendasikan perlunya pengembangan program kesehatan jiwa remaja berbasis keperawatan komunitas.
\end{abstract}

Kata kunci: CBT, Ansietas, Banjir, Remaja

\section{PENDAHULUAN}

Bencana banjir yang dialami individu sebagai kejadian traumatis dapat menyebabkan masalah psikologis yang berkembang menjadi kronis, meluas, berkelanjutan hingga mengalami gangguan kejiwaan ${ }^{(2,25)}$. Dampak psikologis yang sering terjadi paska banjir menimbulkan masalah psikologis seperti ansietas dengan prevalensi $57.5 \%$, gangguan depresi mayor $52.7 \%$, dan PTSD $44.3 \%{ }^{(12,17)}$. Dampak banjir secara psikologis di Indonesia khususnya informasi tentang asnietas yang dialami koraban bencana banjir belum terdapat data yang adekuat. Ansietas merupakan gangguan psikososial yang sering dialami oleh individu (23, 15). Ansietas pada remaja ditunjukkan dengan gejala gugup $10.7 \%$, khawatir atau was-was 9.6\%, timbulnya perasaan sedih, kehilangan nafsu makan atau memiliki kesulitan tidur 6\%, kemampuan menurun dalam berkativitas dan belajar, serta sulit konsentrasi dan marah yang meledakledak 3.9\% ${ }^{(16,22)}$. Perubahan pada konsep diri remaja yaitu sebesar $60 \%$ menyatakan merasa malu dan kurang percaya diri jika wilayahnya terkena banjir, harga diri buruk $53.1 \%$, identitas diri buruk $51.9 \%$, citra diri buruk $50.6 \%{ }^{(18)}$.

Terapi individu yang efektif untuk mengatasi ansietas adalah terapi perilaku kognitif (Cognitive Behaviour Therapy, CBT) terbukti menurunkan ansietas akibat banjir ${ }^{(1,14,7)}$. Terapi ini mengubah pikiran terdistorsi menjadi pikiran yang rasional dan positif serta mengubah perilaku negatif menjadi positif. Penanganan kesehatan jiwa seperti tindakan keperawatan maupun CBT bagi korban banjir terbilang belum pernah diberikan, karena umumnya penanganan lebih berfokus pada penanganan fisik dan perbaikan infrastruktur. Sehingga penanganan secara khusus yang terkait dengan aspek kesehatan jiwa terhadap korban banjir khususnya para remaja. Peneliti mengukur gejala serta tingkat ansietas remaja dan kemudian melakukan intervensi keperawatan ners dan CBT untuk memecahkan masalah ansietas akibat banjir. 


\section{METODE}

Penelitian ini menggunakan quasi-experiment with control group pretest-posttest design untuk membedakan pengaruh intervensi keperawatan ners dan CBT antar kelompok intervensi remaja dengan ansietas. Metode sampling menggunakan Cluster Sampling dan teknik purposive sampling, sebanyak 73 sampel. Instrumen yang digunakan dalam penelitian ini adalah HRS-A (Hamilton Rating Scale for Anxiety) dan instrumen pengukuran kemampuan remaja mengatasi ansietas menggunakan kuesioner yang diadiopsi dari penelitian sebelumnya. Ansietas diberikan terapi intervensi keperawatan dengan teknik relaksasi, hipnotis lima jari dan spiritual serta intervensi keperawatan spesialis dengan CBT. Pengumpulan data dari tahap pretest-postetst dimasukkan dan dianalisis dengan menggunakan software statistic SPSS versi 21. Pengumpulan data dilakukan setelah menjelaskan prosedur dan proses terperinci Tabel 1. Menunjukkan hasil analisis statistik rata-rata ansietas kelompok kontrol sebelum mendapatkan tindakan keperawatan ners sebesar $24.50 \%$ menunjukkan tingkat ansietas sedang. Sementara kelompok kontrol sesudah mendapatkan tindakan ners menjadi $19.92 \%$ berada pada tingkat ansietas ringan dimana nilai ini hampir menuju ke tingkat ansietas sedang. Perbedaan yang diuji dihasilkan untuk kelompok kontrol terdapat perbedaan tingkat ansietas yang bermakna sebelum mendapatkan tindakan ners tingkat ansietas sedang dan sesudah diberikan tingkat ansietas menjadi ringan ( $p$ value $<0.05)$.

Hasil analisis statistik menunjukkan rata-rata ansietas pada kelompok intervensi sebelum mendapatkan tindakan ners dan CBT sebesar $26.00 \%$ menunjukkan tingkat ansietas sedang. Setelah mendapatkan tindakan ners dan CBT menunjukkan rata-rata menjadi $7.37 \%$ dengan tidak adanya ansietas. Hasil uji ini menunjukkan bahwa adanya perubahan penurunan tingkat ansietas yang signifikan dari ansietas sedang menjadi ansietas hilang (tidak ada) pada kelompok sebelum dan sesudah diberikan tindakan ners dan CBT ( $p$-value $<0.05)$. kepada responden. Penelitian dilakukan setelah responden setuju dan mengisi informed consent serta penelitian ini telah lulus uji etik.

\section{HASIL}

Perubahan ansietas yang dialami remaja sebelum dan sesudah pemberian tindaka ners dan CBT pada kelompok intervensi dan tindakan ners untuk kelompok kontrol. Cara uji dalam menentukan perbedaan dianalisis dengan Independent t-test dapat dilihat pada tabel 1 .

Tabel 1. Perbedaan Ansietas Remaja antara Sebelum dan Sesudah Mendapatkan Tindakan Keperawatan Ners dan CBT $(n=73)$

\begin{tabular}{llccc}
\hline Kelompok & & Mean & SD & $\begin{array}{c}\boldsymbol{p} \\
\text { value }\end{array}$ \\
\hline Kontrol & Sebelum & 24.50 & 3.038 & $\mathbf{0 . 0 0 0}$ \\
\hline Ners & Sesudah & 19.92 & 3.805 & \\
\hline Intervensi & Sebelum & 26.00 & 3.734 & $\mathbf{0 . 0 0 0}$ \\
\hline (Ners, CBT) & Sesudah & 13.16 & 4.735 & \\
\hline
\end{tabular}

tindakan keperawatan ners dan CBT pada kelompok intervensi dan tindakan keperawatan ners pada kelompok kontrol di wilayah banjir $(n=73))$

\begin{tabular}{|c|c|c|c|c|}
\hline Variabel & & $\begin{array}{c}\text { Mea } \\
n \\
\text { Diff }\end{array}$ & $\begin{array}{c}S D \\
\text { Selisih }\end{array}$ & p value \\
\hline \multirow{3}{*}{$\begin{array}{l}\text { Kemampuan } \\
\text { Mengatasi } \\
\text { Ansietas } \\
\end{array}$} & Kontr & 0.03 & 4.21 & 0.270 \\
\hline & Interv & 8.48 & 5.10 & 0.000 \\
\hline & Total & & 5.46 & \\
\hline
\end{tabular}

Berdasarkan tabel 2. Bahwa perbedaan kemampuan mengatasi ansietas pada kelompok intervensi mengalami peningkatan dari $20.41 \%$ yaitu kemampuan mengatasi ansietas cukup menjadi $28.89 \%$ yaitu kemampuan baik. Kemampuan remaja dalam mengatasi ansietas pada kelompok kontrol sebalum mendapatkan tindakan keperawatan ners sebesar $21.76 \%$ yaitu kemampuan mengatasi ansietas cukup, dan setelah mendapatkan tindakan ners kemampuan menjadi $21.79 \%$ yaitu kemampuan cukup. Hasil analisis di atas menunjukkan bahwa terdapat perbedaan kemampuan mengatasi ansietas yang signifikan pada kelompok intervensi yang mendapatkan tindakan ners dan CBT ( $p$-value <0.05), bila dibandingkan pada kelompok kontrol dengan pemberian tindakan ners tidak mengalami Tabel 2. Perbedaan kemampuan mengatasi ansietaßerubahan kemampuan secara signifikan pada remaja sebelum dan sesudah mendapatkadengan ( $p$-value $>0.05)$. 


\section{PEMBAHASAN}

Pembahasan ini menguraikan tentang pengaruh CBT terhadap respon ansietas berdasarkan 14 sub variable dan kemampuan remaja mengatasi ansietas. Sub variabel ini kemudian dikategorikan menjadi 4 kategori besar yang menggambarkan respon fisiolofis, repon psikologis, respon kognitif, dan respon perilaku.

\section{Pengaruh Cognitive Behaviour Therapy (CBT) Terhadap Respon Asietas Remaja Di Wilayah Rawan Banjir.}

Respon fisiologis kelompok intervensi sebelum pemberian tindakan keperawatan ners dan CBT yaitu ansietas sedang, setelah pemberian CBT rata-rata respon fisiologis menjadi tidak ada ansietas. Hal ini membuktikan bahwa pada kelompok intervensi sebelum dan sesudah pemberian CBT mengalami penurunan respon fisiologis secara signifikan dari sedang menjadi tidak ada ( $p$-value <0.05). Ansietas terjadi akibat adanya proses regulasi terhadap reseptor tertentu seperti sistem GABA (gamma amino butyric acid), sistem norepinefrin (NE), dan sistem serotonin. GAMA berfungsi mengontrol aktivitas atau tingkat pembakaran dari neuron di bagian otak yang bertanggungjawab dalam menimbulkan ansietas (Stuart, 2013). Faktor biologis ini menjelaskan teori bahwa penyebab terjadinya ansietas akibat adanya gangguan pada neurotransmitter di otak (Videbeck, 2011). Tindakan keperawatan ners ini berupa pemberian pendidikan kesehatan dan terapi relaksasi. Individu menggunakan teknik relaksasi seperti teknik nafas dalam, distraksi (pengalihan pikiran), imaginary guidance, hipnotis lima jari, dan spiritual (Keliat dkk, 2005). Respon fisiologis yang mengalami penurunan secara bermakna setelah pemberian CBT adalah buang air kecil tidak sering, mual berkurang, tidak mudah berkeringat dan kepala tidak pusing, dan merasa lemas berkurang. Hasil penelitian Dunne-Reinholdt dkk, (2015) pemberian CBT pada ansietas memberikan dampak terhadap penurunan tanda gejala termasuk respon fisiologis, karena CBT selain berfokus pada aspek psikologis akan tetapi berpengaruh pada aspek fisik. Kesimpulan dari hasil penelitian dan penjelasan tersebut menunjukkan pemberian tindakan keperawatan ners dan CBT pada remaja terhadap peristiwa traumatik bencana banjir mampu menurunkan respon fisiologis dari ansietas berat menjadi sedang dan ringan.

Respon psikologis kelompok intervensi sebelum pemberian tindakan keperawatan ners dan CBT yaitu ansietas sedang, sedangkan setelah pemberian tindakan keperawatan ners dan CBT menjadi ansietas ringan. Respon psikologis pada masing-masing tingkat ansietas digambarkan dengan perasaan sedih, perasaan berubah-ubah dan tidak tenang. Respon emosional yang ditampilkan remaja cenderung mengekspresikannya berupa kondisi kebingungan dan curiga berlebihan yang merupakan penggambaran reaksi emosi bila mengalami ansietas (Steinberg 2010, 2014; Brenhouse 2011). Perubahan emosi secara fungsional dipengaruhi oleh kemampuan regulasi emosi melalui pembelajaran terhadap pengalaman terdahulu yang tidak menyenangkan, kematangan remaja mengalami stres akan mempengaruhi kondisi psikologis remaja sehingga remaja dapat mengalami gangguan mental emosional (Casey dkk, 2011).

Respon kognitif yang muncul diantaranya adanya rasa malu dengan kondisi, takut dengan pikiran sendiri, firasat buruk, sulit berkonsentrasi, daya ingat menurun, penurunan semangat, takut dan khawatir, dan terkadang mengingat kejadian banjir yang pernah dialami. Remaja yang sedang mengalami ansietas akan memberikan perubahan pada aspek kognitif yang cenderung mengakibatkan hambatan maupun kurangnya kemampuan dalam berfikir sehingga akan mengalami penurunan dalam aktivitas sehari-hari. Ansietas yang dialami individu memberikan perubahan pada kognitif seperti persepsi menyempit, terfokus, penurunan daya ingat dan perhatian. Maka penelitian ini dapat dikatakan bahwa respon kognitif yang timbulkan remaja akibat banjir sesuai dengan penelitian-penelitian yang pernah dilakukan sebelumnya Gosch dkk (2006). Banjir yang dialami remaja memberikan dampak negatif berupa terganggunya harga diri remaja. Individu akan merasa harga dirinya tinggi apabila sering mengalami keberhasilan, sebaliknya bila individu sering mengalami kegagalan dan tidak nyaman berada di lingkungannya maka akan 
mengalami harga diri rendah (Puspitasari dkk, 2014). Individu yang mengalami asnietas akan menimbulkan respon kognitif dimana kemampuan dalam berfikir berupa proses fikir serta isi pikir menunjukkan gejala seperti tidak mampu dalam perhatian, konsentrasi mengalami penurunan, mudah lupa, menurunnya lapang persepsi, dan munculnya perasaan bingung. Ansietas yang dialami remaja juga mempengaruhi perubahan pada fokus perhatian dan konsentrasi (Stuart, 2013). CBT digunakan dalam memodifikasi berbagai pikiran negatif yaitu semua pikiran yang dapat mencetuskan terjadinya ansietas diubah menjadi pandangan positif melalui pendekatan hubungan pola berfikir, proses emosional, dan kesalahan validasi. Peneliti dalam memberikan CBT bersama remaja membantu remaja dalam menyelesaikan permasalahan mengenai ansietas yang dialami pada bencana banjir.

Respon perilaku remaja yang mendapatkan CBT baik sebelum maupun sesudah ternyata secara subjektif menunjukkan perbedaan kurang signifikan. Hal ini dikarenakan remaja menggali perilaku negatif yang telah lalu serta serta mengabaikan dan menganggap bahwa pengalaman yang dialami sekarang terabaikan. Hasil penelitian perilaku negatif yang ditimbulkan diantaranya malas, bolos sekolah, merokok, tauran, mencuri, berbohong, bahkan isolasi terhadap keluarga dan lingkungan. Kondisi remaja yang tidak mampu beradaptasi dalam kondisi peristiwa traumatik dapat menyebabkan kebingungan dalam menentukan pilihan, kesadaran diri berkurang, dan terkadang menunjukkan sifat berlawanan terhadap nilainilai terkait (Steinberg, 2010; Blakemore, Burnett, \& Dahl, 2010). Tahap perkembangan ini remaja mempunyai kerentanan terhadap perilaku yang beresiko dikarenakan selfregulation remaja belum matang serta periode dalam mencari sensasi diri tinggi. Perilaku beresiko yang sering dilakukan remaja diantaranya perilaku kriminal, seks bebas, percobaan bunuh diri, dan ugal-ugalan dalam berkendara (Hollenstein \& Lougheed, 2013).

\section{Pengaruh CBT Terhadap Kemampuan Mengatasi Ansietas.}

Kemampuan remaja yang tinggal di wilayah rawan banjir dalam mengatasi ansietas sebelum mendapatkan tindakan ners dan CBT adalah mempunyai kemampuan cukup. Terganggunya fungsi kognitif serta timbulnya distorsi sangat rentan dialami oleh remaja (Flannery dan Kendall, 2000) dan remaja yang mengalami ansietas dapat menimbulkan gejala ketakutan, perasaan tertekan dan gugup, hilang minat serta gangguan konsentrasi (Stanke dkk, 2012).

Hasil penelitian menunjukkan bahwa kemampuan remaja dalam mengatasi ansietas dengan menerapkan CBT mengalami peningkatan secara bermakna yaitu dari kemampuan cukup menjadi kemampuan baik. Sedangkan pada remaja dengan tidak mendapatkan CBT tidak terjadi peningkatan secara bermakna. Peningkatan kemampuan remaja dalam mengatasi ansietas dengan pemberian CBT juga didukung dengan proses pelaksanaan CBT yang menekankan pada kemampuan dalam melatih cara berfikir dan perilaku positif. Pelaksanaan CBT dalam meningkatkan kemampuan remaja dengan melatih tindakan keperawatan ners yaitu kemampuan dalam mengidentifikasi dan mengenal ansietas berupa tanda, gejala, tingkat ansietas serta dampak yang diakibatnya (Steinberg dkk, 2010; Carter, 2011; Rice, 2008). Setelah remaja mengenal ansietas dan menyadari kondisi yang dialami, sehingga remaja mampu meningkatkan kemampuan mengatasinya. Kemampuan yang dilatih berupa latihan nafas dalam, imagery, hipnotis lima jari dan spiritual. Sesi CBT yaitu mengidentifikasidan melawan pikiran otomatis negatif. Pikiran otomatis negatif yang ditimbulkan berupa takut dan khawatir terhadap banjir, malu dengan kondisi akibat banjir, perasaan gagal dan malas, sulit melakukan aktivitas, kehidupan menjadi tidak jelas, orang lain tidak perduli, serta merasa lelah dengan semua yang dialami. Respon ansietas berupa pikiran otomatis negatif menyebabkan pikiran menjadi terdistorsi sehingga menimbulkan perasaan khawatir, marah, depresi, marah, ataupun perilaku maladaptif (Ellis dkk, 2012; Stuart, 2013). Perilaku negatif yang diakibatkan oleh peristiwa traumatik remaja diantaranya seringnya bolos sekolah, berbohong, merokok, 
tauran, malas dalam aktivitas, mencuri, isolasi terhadap teman dan lingkungan, serta kegiatan yang diluar kebiasaan. Kemampuan remaja dalam mengubah perilaku ini dilatih dengan mengantinya menjadi perilaku positif. Selanjutnya kemampuan remaja dalam mencegah kekambuhan berupa memberikan kewaspadaan terhadap pengalaman traumatik banjir dalam diri dan strategi koping dalam mengontrol ansietas. Kemampuan dalam memanfaatkan pelayanan kesehatan, cara penanganan ansietas, dan mampu memanfaatkan terapi generalis dan CBT dalam mengurangi ansietas. Sehingga dapat dinyatakan bahwa pembelajaran pada perilaku diawali dan terbentuk dari adanya stimulus yang diberikan secara berulang dan berkesinambungan.

\section{KESIMPULAN}

Intervensi keperawatan ners dan Cognitive Behaviour Threapy (CBT) memberikan pengaruh yang signifikan terhadap penurunan ansietas remaja di wilayah rawan banjir. Intervensi keperawatan dan CBT memberikan pengaruh yang signifikan terhadap penurunan ansietas dua kali lebih besar dari remaja yang hanya diberikan dengan intervensi keperawatan ners. Penelitian ini merekomendasikan perlunya pengembangan program kesehatan jiwa remaja berbasis keperawatan komunitas.

\section{DAFTAR PUSTAKA}

1. Aduriz, M. E., Bluthgen, C., \& Knopfler, C. (2009). Helping Child Flood Victims Using Group EMDR Intervention in Argentina: Treatment Outcome and Gender Differences. American Psychological Association International Journal of Stress Management vol. 16, No. 2, p 138-153.

2. Berry, H. L., Bowen, K., \& Kjellstrom, T. (2010). Climate change and mental health: a causal pathways framework. International Journal of Public Health, vol 55(2), p 123-132.

3. Blakemore, S. J., Burnett, S., \& Dahl, R. E. (2010). The role of puberty in the developing adolescent brain. Human Brain Mapping, vol 31, p 926-933.
4. Brenhouse, H. C., \& Andersen, S. L. (2011). Developmental trajectories during adolescence in males and females: A cross-species understanding of underlying brain changes. Neuroscience and Biobehavioral Reviews, vol 35, $p$ 1687-1703.

5. Casey, B. J., Jones, R. M., \& Somerville, L. H. (2011). Braking and accelerating of the adolescent brain. Journal of Research on Adolescence, vol 21, p 21-33.

6. Carter, S. (2011). Managing Anxiety in Children. Diunduh dari http://www.lianalowenstein.com/article_carter. pdf.

7. Dunne-Reinholdt, M. L., Mogg, K., Vangkilde, S. A., dkk. (2015). Attention Control and Attention to Emotional Stimuli in Anxious Children Before and After Cognitive Behavioral Therapy. Springer Science Cogn Ther Res vol 39, p 785-796.

8. Ellis, B. J., Giudice, M. D., Dishion, T. J., Figueredo, A. J., Gray, P., Griskevicius, V., dkk. (2012). The Evolutionary Basis of Risky Adolescent Behaviour: Implications for Science, Policy, and Practice. American Psychological Association Developmental Psychology Vol. 48, No. 3, p 598-623.

9. Flannery-Schroeder, E. C., \& Kendall, P. C. (2000). Group and Individual CognitiveBehavioral Treatments for Youth with Anxiety Disorders: A Randomized Clinical Trial. Cognitive Therapy and Research, Vol. 24, No. 3, p 251-278.

10.Gosch, E. A., Flannery-Schroder, E., Mauro, C. F., \& Compton, S. N. (2006). Priciples of Cognitive Behavioral Therapy for Anxiety Disorder in Children. Journal of Cognitive Psychotherapy, vol 20 (3), p 247. 11.Hollenstein, T., \& Lougheed, J. P. (2013). Beyond Storm and Stress, Typicality, Transactions, Timing, and Temperamant to Account for Adolescent Change. American Psychological Association. Vol. 68, No. 6, p 444-454.

12.Kar, N., Mohapatra, P. K., Nayak, K. C., Pattanaik, P., Swain, S. P., \& Kar, H. C. (2007). Post-traumatic stress disorder in children and adolescents one year after a super-cyclone in Orissa, India: exploring cross-cultural validity and vulnerability factors. BMC psychiatry, vol 7(1),p 8-13. 
13.Keliat, B. A., dkk. (2005). Modul Basic Course Community Mental Health Nursing, Kerjasama FIK UI dan WHO

14.Koucky \& Nixon. (2012). Stress Disorder: Conceptual Issues and Treatment a Outcomes. Cognitive and Behaviour Practice, 19 (2012), p 437-450

15. Mason, V., H. Andrews, dkk. (2010). The psychological impact of exposure to floods. Psychology Health Medicine, vol 15(1), p 61-73.

16. Otto, K., Boos, A., Dalbert, C., Schöps, D. \& Hoyer, J. (2006). Posttraumatic symptoms, depression, and anxiety of flood victims: The impact of the belief in a just world. Personality and Individual Differences, vol 40, p 10751084.

17. Paranjothy S., dkk. (2011). Psychosocial impact of the summer 2007 flood in England. BMC Public Health 2011, vol 11, p 145.

18. Puspitasari, D. L., Mubin, M. F., \& Targunawan. (2014). Gambaran Psikologis: Konsep Diri pada Anak Remaja di Wilayah Banjir Rob. Jurnal Ilmu Keperawatan dan Kebidanan (JIKK).

19.Rice, C. L. (2008). Reducing Anxiety in Middle School and high School Students: a Comparison of Cognitive Bahvioral Therapy and Relaxation Training Approach. Disertation The Faculty of Department Special Education, Rehabilitation, and School Psychology, University of Arizona.Stuart, G. W. (2013). Principles and Practice of Psychiatric Nursing. 10 th Ed. St.Louis: Mosby.

20.Steinberg, L. (2010). A behavioral scientist looks at the science of adolescent brain development. Brain and Cognition vol 72, $p$ 160-164.

21.Steinberg, Laurence. (2014). Adolescence Tenth Edition. New York: McGraw-Hill.

22.Stanke, Carla ., Murray, Virginia ., Amlôt, Richard ., dkk. (2012). The Effects of Flooding on Mental Health: Outcomes and Recommendations from a Review of the Literature. PLOS.

23. Tunstall, S., Tapsell, S., Green, C., Floyd, P., \& George, C. (2006). The health effects of flooding: social research results from England and Wales. J Water Health, vol 4, p 365-380.
24.Videbeck, S. L. (2011). Psychiatric Mental Health Nursing (4rd Ed). Philadelpia: Lippincott Williams \& Wilkins.

25.Zahran, S., Peek, L., Snodgrass, J. G., Weiler, S., \& Hempel, L. (2011). Economics of disaster risk, social vulnerability, and mental health resilience. Risk analysis, vol 31(7), p 11. 